\title{
Women's Leadership Characteristics and Its Impact in Developing the Psychological Capital: Test of the Moderating Role of Experience Power (Analytical Study from the Perspective of Subordinates in Private Education Schools in Amman)
}

\section{Ahmed Ali Salih and Maryam Salman AI-Dulaimi*}

Department of Business Administration, Middle East University, Amman, Jordan

\begin{abstract}
This study aimed to demonstrate impact of the characteristics of women's leadership at the psychological capital development, with the experience power as a moderating role.

To achieve the objectives of the study were used descriptive and analytical approach to the appropriateness of the nature of this study, which used the questionnaire as a key tool for the study, and after testing the validity and reliability of the questionnaire, (379) questionnaires have been distributed to identify the study sample who occupy the following administrative levels: (teachers and administrators), it showed that there are (3) questionnaires are not valid for analysis, and thus became the number of valid questionnaires for analysis (376) questionnaires, at a rate $(99.2 \%)$ of the recovered questionnaires.

The researcher used group of descriptive and deductive analysis using SPSS-21. The study reached several conclusions, including: the practice of women's leadership characteristics is high, in the special education schools in Amman governorate, and the level of the psychological capital is average between subordinates, also the experience power has a high level. And there is an impact of practicing the women's leadership characteristics on psychological capital, and the presence of statistically significant impact for the characteristics of the women's leadership characteristics with its five dimensions in the psychological capital development, in the presence of the experience power moderating role in private education schools.

And in view of these results, the study recommended a number of recommendations, including, boosting the practices of women's leadership characteristics for the leader by increasing top management support, and taking a good care with the psychological capital and its effect on the individual work in the organization. Finally, to continue seek and search in women's leadership characteristics and the power of experience and connect them with educational sector, as well as encourage investment with the psychological capital.
\end{abstract}

Keywords: Women's leadership characteristics; Psychological capital; Experience power

\section{Introduction}

In today's global organizations competition, there are many challenges facing organizations. There is an urgent need to develop, enrich and support the organization human resources capacities to meet these challenges. Psychological capital is a contemporary theme that has a significant impact on the development and increase the productivity of human resources [1].

Psychological capital needs influential factors that promote and increase its investment, leadership is generally one of these influences. Studies have revealed that there is an impact of leadership in psychological capital [2]. Women leadership is one type of the leadership administration types that affects psychological capital because it represents a set of characteristics that enable women to make their own decisions and increase their self-confidence to assume leadership and managerial positions and to develop their ability to achieve superior performance [3]. Women leadership consider a new modern concept that has not been written and researched sufficiently about and there are studies that try to close that scientific gap of that term [4]. Also there are studies indicating a small number of women who are in positions of senior management in organizations [5] not because they lack sufficient competence, skills and expertise, but because nowadays there are many obstacles and barriers women face in organizations [6].

The Rouleau-Carroll [7] study has revealed that women leadership characteristics, especially self-efficacy and patience, contribute in the development of social aspects and it is well known that psychological capital is a component of social aspects.

Experience power plays a role in stimulating the impact of women's leadership in developing and improving psychological capital variables [8]. Many researchers who have conducted studies and interviews reported that women leaders gained knowledge through experience, and that knowledge led them to many successful experiences that they had hoped for as they broke barriers and overcome obstacles, then they applied this acquired knowledge in a flexible way which led them to succeed as women leaders.

${ }^{*}$ Corresponding author: Maryam Salman Al-Dulaimi, Researcher, Master of Business Administration, Middle East University, Amman, Jordan, Tel: 9626479 0222; E-mail: maryam.salman@live.com

Received November 16, 2017; Accepted December 14, 2017; Published December 19, 2017

Citation: Salih AA, Al-Dulaimi MS (2017) Women's Leadership Characteristics and Its Impact in Developing the Psychological Capital: Test of the Moderating Role of Experience Power (Analytical Study from the Perspective of Subordinates in Private Education Schools in Amman). Int J Econ Manag Sci 6: 484. doi: 10.4172/2162-6359.1000484

Copyright: ( 2017 Salih AA, et al. This is an open-access article distributed unde the terms of the Creative Commons Attribution License, which permits unrestricted use, distribution, and reproduction in any medium, provided the original author and source are credited. 
Citation: Salih AA, Al-Dulaimi MS (2017) Women's Leadership Characteristics and Its Impact in Developing the Psychological Capital: Test of the Moderating Role of Experience Power (Analytical Study from the Perspective of Subordinates in Private Education Schools in Amman). Int J Econ Manag Sci 6: 484. doi: 10.4172/2162-6359.1000484

Page 2 of 10

It appears that leadership is strongly linked to the experience power, particularly women's leadership in influencing other variables [9]. Weidenfeller noted that the power owned by the leader woman derived from the experience power possessed by the leader woman which is forgotten by the woman leader who uses their functional title and functional power instead of using the greater and more effective power, with which a leader woman can win any challenge or obstacle.

Javidanand Walker said: "We can develop and improve psychological capital variables through the experience power to be reflected on the person's personality and improving his performance and leadership".

\section{Problem of the Study}

The problem of the current study was diagnosed from two sources, namely literature and qualitative study. On the first side, literature indicated that there was a lack of studies on women's leadership and could not give us a full and clear idea of women's experiences as leaders. Drasin [10] noted that there is a relationship between experience and psychological capital, but there is a scientific gap which researchers are trying to enrich and close through studies. As the study [11] has shown, the work on the experience power is not supported and is still not clear because it has not been discussed in literature sufficiently and clearly.

After the researcher benefited from the results of the literature, she conducted a limited qualitative study by conducting open, unstructured interviews in five private schools (Modern Systems, Educational Growth, Arab Model, Oxford, Sands). The study sample includes school principals, departments, teachers and administrators working in these schools within the governorate of Amman. The researcher has concluded that there is a problem of poor investment in psychological capital which needs to bring to attention. This problem has left many of the competencies unrealized in schools and results in low teamwork spirit which reflected in the low overall performance of schools and their weak competitiveness compared to other schools. When discussing the issue of women's leadership and its characteristics, the interviewees stressed the importance of this topic and its potential role in investing in psychological capital. The researcher noted that most of the interviewees relied on formal and vertical power without giving much attention to the experience power.

Based on the above, the problem of the current study can be identified in the following main question:

What is the impact of the women's leadership characteristics in developing the psychological capital, with the presence of experience power as a moderating role?

\section{Objectives of the Study}

The current study attempts to explore the impact of the women's leadership characteristics in developing the psychological capital with the presence of experience power as a moderating role through the following:

1. Providing a theoretical framework for the study variables in order to explain their concepts, dimensions, variables, and the nature of the relationship between them according to the theoretical literature and previous studies.

2. Descriptions of the levels of practice of the basic study variables (women leadership, psychological capital, and experience power) in the schools surveyed by the researcher.

3. Identifying the direct impact of the women's leadership characteristics in developing the psychological capital in the schools surveyed.

4. Exploring the role of the experience power within the impact of women's leadership characteristics in developing the psychological capital as a moderating role in the surveyed schools.

\section{The importance of the study}

The importance of this study can be summed up as follows:

1. This study carries applied importance relevant to schools through shedding light on vital and important issues such as women leadership and experience power and their role in promoting the psychological capital.

2. The significance of the study emerges from the importance of private schools as they contribute to spreading knowledge and rising generations on the one hand and seek to achieve distinct results to maintain their reputation on the other hand.

3. The significance of this study is manifested through its attempt to pave the way for researchers to expand the scope of the study of women leadership and psychological capital and the impact of experience power on them.

4. Finally, the importance of the study is highlighted via its attempts to offer recommendations to officials and decision-makers on how to invest in women leadership and its characteristics and psychological capital, along with its variables, with the presence of experience power.

\section{Study hypotheses}

The first main hypothesis:

H01: The five women's leadership characteristics (empathy, collaboration, patience, intuitiveness and composure) have no impact in developing the psychological capital (self-efficacy, optimism, hope and resiliency) in private schools at $(\alpha \leq 0.05)$.

The second main hypothesis:

H02: There is no change in the impact of women's leadership characteristics (empathy, collaboration, patience, intuitiveness and composure) in developing the psychological capital with the presence of experience power as a moderating role in private schools at ( $\alpha \leq$ $0.05)$.

\section{Study model}

Figure 1 illustrates the virtual model to the impact of women's leadership characteristics (empathy, collaboration, patience, intuitiveness and composure) in developing the psychological capital (self-efficacy, optimism, hope, and resilience) with the existence of power experience as a moderating role.

Characteristics of independent variable: Based on RouleauCarroll [7]; Desvaux and Devillard [12].

Variables of dependent variable: Based on Luthans et al. [13]; Corner [14]; Bockorny [15].

Moderating role: Based on Toogood [16]. 
Citation: Salih AA, Al-Dulaimi MS (2017) Women's Leadership Characteristics and Its Impact in Developing the Psychological Capital: Test of the Moderating Role of Experience Power (Analytical Study from the Perspective of Subordinates in Private Education Schools in Amman). Int J Econ Manag Sci 6: 484. doi: 10.4172/2162-6359.1000484

Page 3 of 10

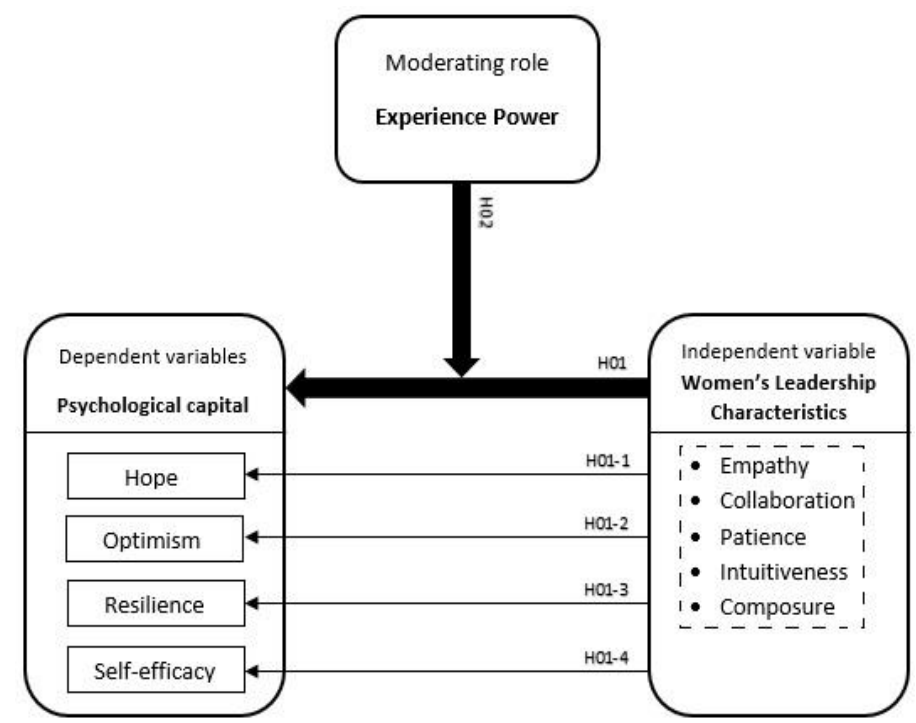

Figure 1: Study model. Source: The researcher designed the model structure.

\section{The Theoretical Framework and the Literature of the Study}

\section{Women leadership}

The literature base on women's leadership is scarce and limited in spite of its importance, especially in the Arab world as per the researcher's limited knowledge. As Heckman [5] mentioned, women's leadership is a rare subject, it is a new term which was first mentioned in the 1975 Mexico Forum held by the United Nations. That year was considered an international year for women as its motto was "Equality, Development, Peace" followed by several other conferences. Beijing conference held in in 1995 was one of the most important conferences which developed concepts relevant to our contemporary time and its nature. Also the researchers examined the trait women leadership theory [17].

Leadership in general means the ability to guide and influence others. It also means the ability to guide and encourage change in the group [18]. The approach that ensures women do the administrative duties is the women leadership approach.

Women Leadership is defined as a set of characteristics and behaviors related to women such as the development of people, role modeling, expectations and rewards, inspiration and decision-making sharing, which enable women to perform leadership functions better than men. Also, it is defined as a leadership style characterized by a range of characteristics including collaborative work, relationship building, and caring of others [19].

The definitions show that women leadership is hard and challenging work because it requires employing many skills and techniques to succeed. Women sometimes need to use different techniques to gain professional credibility, or even women need to adopt male characteristics to fit with their male counterparts. When integrated into leadership, the leader moves to intellectual work, emotional intelligence, relational skills, insight, and a great deal of personal strength. Leadership is therefore not easy. A person who aspires to be a leader needs to practice leadership and skills developing to become a leader.
Empathy: Women leaders have the ability to communicate with colleagues more effectively and this gives women the strength in their leadership because they can act in critical situations [20] and make a decision rationally considering the circumstances surrounding the subordinates. Knowing that one of the strategies exercised by the leader woman in dealing with subordinates is to talk and listen to them and communicate with them personally and discuss their issues. This strategy also helps the leader woman in the implementation of business strategies [21].

Patience: It is the endurance in the face of adversity, remaining composed and self-possessed under stress and guiding the thought in the right direction to reach a rational and sensible solution. RouleauCarroll stated patience as dealing with the situation as a whole, not from a single angle, which is the deeper understanding of circumstances beyond the norm. Fahmy [22] stated that familiarity with leadership is better representation of the spirit of patience.

Collaboration: Partnering with people to achieve the goals of the organization through good listening and consultation among them which leads to democratic decisions making, resulting in high morale among the workers in the organizations and thus increases loyalty of staff towards the organization [23]. As pointed out in McCullough, being an effective leader requires collaboration and presence alongside the employees, which is the leadership key in order to make the right decision.

Intuitiveness: The ability of women to understand the work that must be done and the ability of women to understand things without speaking clearly and explicitly which means the women understand things through her intuition without any explanation or talk about the subject and It is the ability of a leader to be flexible in thinking when facing a difficulty in achieving a particular goal, that is, sometimes moving from one goal to another to reach the desired goal.

Composure: It is to endure the difficulties and hardships facing the leader to reach success and the desired goals which are very important qualities in the leadership of a woman for her sensitivity. For example, it is very important in school leadership because it is the basis of work in schools. 
Citation: Salih AA, Al-Dulaimi MS (2017) Women's Leadership Characteristics and Its Impact in Developing the Psychological Capital: Test of the Moderating Role of Experience Power (Analytical Study from the Perspective of Subordinates in Private Education Schools in Amman). Int J Econ Manag Sci 6: 484. doi: 10.4172/2162-6359.1000484

\section{Psychological capital}

The psychological capital term emerged in the late 1990s when was mentioned by the psychologist Martin Seligman whose goal was to focus on the positive qualities of the individual. The basis of this term is that individuals have positive qualities; these qualities support the performance of the individual which reflects positively on the quality of their work performance. So, for an individual to be able to face the challenges, to develop his work and to excel in it, he must enjoy good psychological health. It is known that the term "capital" is heavily used in the field of economics and finance, but over the time this term has been used within human resources to express and represent the value of human resources. Accordingly and over the time, several terms have emerged such as human capital, intellectual capital, social capital and psychological capital.

Avey et al. defines psychological capital as a positive individual state of mind that has relevance to individual behavior and performance at work. Corner identified it as generating information that is capable of being applied in education to create an appropriate organization that meets the requirements of the $21^{\text {st }}$ century as well as information on leadership skills to create a necessary change in individuals to achieve prosperity and achieve unique organization potential. In theory, psychological capital is associated with authentic leadership and is defined by Luthans et al. as the development of the positive mental state of the individual, Chan defines it as the increase of the positive psychological ability of the individual which is affected by his experience and Poon [24] defines it as the positive psychological ability of an individual that is built similar to hope, self-efficacy, resilience, and optimism.

Hope: It is the ability to find ways and means to reach the goals that the person aspires to achieve through the positive psychological state. If these ways and means do not work, the individual would think of other ways to reach the aspired goals and keep the hard work and perseverance. As Luthans et al. have pointed out, hope is the perseverance of the hard work till achieving goals and redirecting paths in order to achieve high efficiency. This is the main difference between it and the traditional definition of hope which means wishing to achieve something and individual may be disappointed if it is not achieved without retrying.

Thus, hope helps to reach the goals successfully because according to Peterson and Byron [25] hope is related to the employee's behavior and excellence in work performance. Besides, hope motivates the employee to find solutions to problems creatively by integrating the individual step by step in the way to achieve the desired goals [26].

Self-efficacy: It is the person's belief in his or her own abilities and skills, regardless of the surroundings. Furthermore, it is the capability to be confident and successful and to transmit those capacities in a motivating and catalytic manner to achieve the set out goals [27]. Hence, we could conclude that there is a positive relationship between selfefficacy and work performance. It is also the interaction of the staff of the organization and the expression of their views without fear or doubt [28]. When a person trusts his abilities, this trust and confidence will be reflected on his life and this is the principle that underlies his behavior that leads him to the goal he wants to achieve. When the individual believes that he can achieve the goal, he will have the motivation to persevere to reach his goals and to face the difficulties. If the individual has confidence, he will have the strength to confront and change and thus achieve the goal [29].
There's no doubt that self-efficacy effect on how the worker can see the work and the organization he work in, so the people who have that dimension they have the five characteristics as Corner mentioned (put high level goals and challenges duties, search for challenge, have selfmotivation, committed to timeline to achieve the goals, when they face barriers they keep working until they get the desired goal).

Resilience: Psychologists began to draw attention to the term resiliency during the 1970 because of family and experimental circumstances and was defined as the distinct outputs of the individual after going through difficult situations [30]. It also reflects rebalancing and recomposing after facing obstacles and problems and the ability to overcome them successfully and sustainably. It is the person's ability to rebalance after the setbacks and obstacles that a person faces and that is what keeps the person trying. In positive psychology, resilience means the positive adjustment to adversity, the ability to deal with adversity [31], in addition to increased job commitment and responsibility at work and success in learning from those obstacles and dealing with them more positively in the future.

Optimism: is the basis of Psychological capital as it is positively linked to future events which includes positive emotions and motivation with a realistic assessment of these events as to whether they can occur which increases the person's effectiveness and hope [32]. This is due to the nature of optimism as it is constantly changing. That is to talk about the present and the future in a successful, bright and positive way. Several studies have shown that optimism has a positive effect in raising the level of performance in several areas. It means the individual perseveres and continues his activity to achieve his desired goals. This is done by expressing one's appreciation of others for success through learning from mistakes and taking appropriate risks to achieve the goals to be reached through research, hope and ambition towards positive experiences. Optimism reflects a person's perception of events successfully or unsuccessfully. The optimistic person views the events successfully and attributes the success to internal factors. The pessimistic person attributes the success to temporary external factors. Of course, the individual cannot control the external factors that limit reaching the goal, but the optimist focuses on the possibilities and opportunities to achieve those goals.

Experience power: Before proceeding with the definition of experience power, it is necessary to refer to a larger issue which is the organizational power. It means the ability to move the organization's various resources in order to achieve the goals or influence the decisions of others to determine their behavior and fix the direction of future work or make individuals do things they didn't originally want to do $[33,34]$. Thus, the organizational power means the ability to successfully influence others [35].

Power is the ability of the individual to pressure others to exploit their abilities to serve certain ends [36]. The power is also known as the control of the resources and behavior of others [37]. It is also the influence that a person exercises over others through his identity [38].

The power of experience is defined as: ability derived from being excellent in a field of human knowledge. It also defines as the ability that the manager develops as a result of his experience and knowledge of the tasks performed by his employees giving him influential effects on the behavior of the employees and making them submissive to his instructions and guidance. The power of experience also depends on the personal characteristics of the manager. Jones [39] defined the experience power as the ability of an individual or group of individuals to resist conflict to achieve a specific goal or the planned goal. Bal et 
Citation: Salih AA, Al-Dulaimi MS (2017) Women's Leadership Characteristics and Its Impact in Developing the Psychological Capital: Test of the Moderating Role of Experience Power (Analytical Study from the Perspective of Subordinates in Private Education Schools in Amman). Int J Econ Manag Sci 6: 484. doi: 10.4172/2162-6359.1000484

Page 5 of 10

al. [40] defined the experience power as the effect of communication and development of specialized or perceived knowledge. Robbins \& Judge defined it as the manger's influence on workers through their own knowledge, skills and practical experience. It is worth mentioning that managers in organizations are very important because they are responsible for achieving the objectives of the organization and the employees for their experience power [41].

Therefore, experience power is linked to leadership [42]. The experience power focuses on the feelings of individuals, as the role of the power is increasing and focusing on the feelings of individuals and behaviors and not limited to coercion; it is wise to be the experience of leaders as a screen reflecting dealing with all behaviors, whether positive or negative with all the their consequences [43]. The experience power is the ability of the leader to influence the followers for his scientific qualifications, practical and scientific experience, training and special expertise [44].

\section{Method and Procedures}

\section{Private schools}

Each licensed, non-governmental educational institution teaches the curriculum and textbooks prescribed in the government educational institutions. It has a commercial register with the Ministry of Industry and Commerce/the General Manager of the Companies and a business certificate clarifying the nature of the company, the names of the members, the authorized person, the capital, the objectives of the company and other items included therein. (Law of Education No. 3 of 1994; Article 2 of the Regulations for the Establishment and Licensing of Private and Foreign Educational Institutions No. 130 of 2015 (Ministry of Education - Department of Legal Affairs)). The above details show that besides being educational organizations with educational missions, private schools are business organizations run like a business [45-47].

\section{Methodology of the study}

The current study is a purposeful study of quantitative and qualitative nature. It has adopted the analytical descriptive research approach which is the most appropriate method for achieving the objectives of the present study and answering its questions.

\section{Study population and study sample}

To achieve the objectives of the study, the studied variables require organizations that are led by women or women taking part in their leadership and management, so the field of study will be the private schools in the city of Amman (549) schools (Ministry of Education, Department of Planning and Educational Research).

The study population consists of (21615) teachers and administrators (administrative and financial staff, technical staff and service personnel).

Table 1 shows the characteristics of the individuals in the study sample: (gender; age; educational qualification; number of years of experience; job location).

The results of Table 1 :

1. The highest percentage of the members in the gender variable analysis unit is female because females are more attracted to work in schools.

2. The highest percentage of members in the age variable analysis unit is under the age of 30 years which indicates that the highest percentage is from the young category.

3. The highest percentage of the members in the analysis unit has a bachelor degree which indicates a high attraction of the university degree holders and reflects the availability of scientific knowledge.

4. The highest proportion of the members in the analysis unit were of 5 years' experience or less, which are the beginning of the career path and is expected to give objective answers related to the their future.

5. The highest percentage of the members in the unit of analysis work as "teachers".

6. The previous data confirms that all groups have worked under

\begin{tabular}{|c|c|c|c|c|c|}
\hline \multicolumn{3}{|c|}{ Distribution of the unit of analysis by sex variable } & \multicolumn{3}{|c|}{ Distribution of the unit of analysis by number of years of experience variable } \\
\hline Sex & Recurrence & Percentage (\%) & Experience & Recurrence & Percentage (\%) \\
\hline Male & 93 & 24.7 & 5 years and less & 140 & 37.2 \\
\hline Female & 283 & 153 & From $6-10$ years & 123 & 32.7 \\
\hline Total & 376 & 100 & From $11-15$ years & 57 & 15.2 \\
\hline \multicolumn{3}{|c|}{ Distribution of the unit of analysis by age variable } & 16 years and more & 56 & 14.9 \\
\hline Age & Recurrence & Percentage (\%) & Total & 376 & 100 \\
\hline Less than 30 years & 153 & 40.7 & \multicolumn{3}{|c|}{ Distribution of the unit of analysis by job title variable } \\
\hline From $31-40$ years & 139 & 37 & Job title & Recurrence & Percentage (\%) \\
\hline From $41-50$ years & 58 & 15.4 & Teacher & 230 & $6 \mathrm{~L} 2$ \\
\hline 51 year and more & 26 & 6.9 & Administrative & 146 & 38.8 \\
\hline Total & 376 & 100 & Total & 376 & 100 \\
\hline \multicolumn{3}{|c|}{$\begin{array}{c}\text { Distribution of the unit of analysis by educational } \\
\text { qualifications variable }\end{array}$} & \multicolumn{3}{|c|}{$\begin{array}{c}\text { Distribution of the unit of analysis by number of years worked under the leadership of women } \\
\text { variable }\end{array}$} \\
\hline $\begin{array}{l}\text { Educational } \\
\text { qualification }\end{array}$ & Recurrence & Percentage (\%) & Category & Recurrence & Percentage (\%) \\
\hline Diploma & 58 & 15.4 & 5 years and less & 191 & 50.8 \\
\hline Bachelor & 239 & 63.6 & From 6-10 years & 104 & 27.7 \\
\hline master & 44 & $1 \mathrm{~L} 7$ & From $11-15$ years & 46 & 12.2 \\
\hline High diploma & 25 & 6.6 & 16 years and more & 35 & 93 \\
\hline $\mathrm{PhD}$ & 10 & 2.7 & Total & 376 & 100 \\
\hline Total & 376 & 100 & & & \\
\hline
\end{tabular}


Citation: Salih AA, Al-Dulaimi MS (2017) Women's Leadership Characteristics and Its Impact in Developing the Psychological Capital: Test of the Moderating Role of Experience Power (Analytical Study from the Perspective of Subordinates in Private Education Schools in Amman). Int J Econ Manag Sci 6: 484. doi: 10.4172/2162-6359.1000484

Page 6 of 10

the leadership of women, which helps us to obtain objective answers to the variables of the study.

\section{Results of the Statistical Analysis of the Study and Hypothesis Testing}

The results of the statistical analysis of the responses of the members in the analysis unit will be reviewed on the variables that were adopted by presenting the initial statistical indicators of their responses through the arithmetical averages and standard deviations of all study variables and relative importance, as shown in the following Tables 2-4.

Table 2 shows the responses of the study sample on the level of practice of women leadership characteristics related to the private schools in Amman Governorate. Where the arithmetic averages of the level of practice of women leadership characteristics in private education schools ranged from (3.942-4.162) with a total average of (4.044) on the five-point scale, which indicates the high level of practice of women leadership characteristics related to the private education schools in Amman Governorate. Exercising of "empathy" was in the first place while the practice of "collaboration" ranked fifth and final.

Arithmetical averages, standard deviations and the calculated value of the responses of sample members at the level of psychological capital status.

Table 3 shows the responses of the study sample on the level of psychological capital status in private schools in Amman Governorate ranging from $(3,266-3.13)$, with an arithmetical average of (3.296) on the five-point scale, which indicates the level of the average state of psychological capital in the private education schools in Amman Governorate. The state of "optimism" came first, while the state of "resilience" ranked fourth and final.

Arithmetical averages, standard deviations and the calculated value of the responses of sample members at the level of experience power.

Table 4 shows the answers of the study sample to the statements related to the experience power in private education in Amman

\begin{tabular}{|c|c|c|c|c|c|c|c|}
\hline $\mathbf{T}$ & $\begin{array}{l}\text { Women's leader ship } \\
\text { characteristics }\end{array}$ & $\begin{array}{l}\text { Average } \\
\text { arithmetic }\end{array}$ & $\begin{array}{l}\text { Standard } \\
\text { deviation }\end{array}$ & $\begin{array}{l}\text { Value of T } \\
\text { calculated }\end{array}$ & $\begin{array}{c}\text { Level of } \\
\text { significance }\end{array}$ & $\begin{array}{c}\text { Order of } \\
\text { importance of } \\
\text { practice }\end{array}$ & Practice level \\
\hline 1 & Empathy & 4.162 & 0.829 & 19.576 & 0 & 1 & High \\
\hline 2 & Collaboration & 3.942 & 0.843 & 24.316 & 0 & 5 & High \\
\hline 3 & Patience & 3.944 & 0.876 & 23.336 & 0 & 4 & High \\
\hline 4 & Intuitiveness & 3.944 & 0.834 & 23.367 & 0 & 3 & High \\
\hline 5 & Composure & 4.147 & 0.843 & 19.6 & 0 & 2 & High \\
\hline \multicolumn{2}{|c|}{$\begin{array}{c}\text { Average and mean SD for women's leadership } \\
\text { characteristics }\end{array}$} & 4.044 & 0.756 & 24.499 & 0 & & High \\
\hline
\end{tabular}

Table 2: Shows the responses of the study sample on the level of practice of women leadership characteristics.

\begin{tabular}{|c|c|c|c|c|c|c|c|}
\hline $\mathbf{T}$ & Psychological capital status & Average arithmetic & $\begin{array}{l}\text { Standard } \\
\text { deviation }\end{array}$ & Value of $\mathrm{T}$ calculated & $\begin{array}{l}\text { Sig level of } \\
\text { significance }\end{array}$ & $\begin{array}{l}\text { Order importance } \\
\text { of practice }\end{array}$ & Practice level \\
\hline 1 & Self-efficacy & 3.296 & 0.396 & 83.232 & 0 & 3 & Average \\
\hline 2 & Optimism & 3.313 & 0.446 & 73.235 & 0 & 1 & Average \\
\hline 3 & Hope & 3.307 & 0.433 & 75.761 & 0 & 2 & Average \\
\hline 4 & Resilience & 3.266 & 0.435 & 77.173 & 0 & 4 & Average \\
\hline \multicolumn{2}{|c|}{$\begin{array}{l}\text { Average mean and general SD for } \\
\text { psychological capital status }\end{array}$} & 3.296 & 0.319 & 103.48 & 0 & & Average \\
\hline
\end{tabular}

Table 3: Shows the responses of the study sample on the level of psychological capital.

\begin{tabular}{|c|c|c|c|c|c|c|c|}
\hline $\mathbf{T}$ & Experience power & $\begin{array}{l}\text { Average } \\
\text { arithmetic }\end{array}$ & standard & Value of $\mathbf{T}$ & $\begin{array}{l}\text { Sig of } \\
\text { level }\end{array}$ & $\begin{array}{l}\text { Order } \\
\text { importance of }\end{array}$ & $\begin{array}{l}\text { Practice } \\
\text { level }\end{array}$ \\
\hline 35 & My leader deals with the challenges wisely by consulting her practical experience & 4.199 & 0.912 & 17.017 & 0 & 1 & High \\
\hline 36 & My leader analyse problems from multiple angels to find effective solutions & 4.066 & 0.939 & 19.257 & 0 & 5 & High \\
\hline 37 & My leader perform her tasks efficiently because she have professional expertise & 4.138 & 0.927 & 18.009 & 0 & 2 & High \\
\hline 38 & My leader contribute in decision making objectively & 4.077 & 0.93 & 19.229 & 0 & 4 & High \\
\hline 39 & My leader has acquaintance helped her to be in the right place & 4.106 & 0.971 & 17.841 & 0 & 3 & High \\
\hline 40 & My leader acquaintance impact on the quality performance & 3.933 & 1.125 & 18.368 & 0 & 14 & High \\
\hline 41 & The experience of my leader reflect on the development of our skills in the work & 4.042 & 1.011 & 18.363 & 0 & 6 & High \\
\hline 42 & $\begin{array}{c}\text { My leader abilities contribute to the development of the organisations policies towards } \\
\text { outstanding performance }\end{array}$ & 4.031 & 0.99 & 18.959 & 0 & 8 & High \\
\hline 43 & $\begin{array}{l}\text { My leader solve the problems between workers in a scientific manner result from a } \\
\text { successful work experience }\end{array}$ & 3.992 & 1.034 & 18.902 & 0 & 13 & High \\
\hline 44 & My leader behaviour effect on promote our positive attitude toward work & 4.034 & 1.004 & 18.632 & 0 & 7 & High \\
\hline 45 & My leader keen to work on transferring her expertise to all workers without exception & 3.994 & 1.097 & 17.756 & 0 & 12 & High \\
\hline 46 & My leader develop our ability to make decisions through involving us in dialogue & 4.013 & 1.064 & 17.974 & 0 & 10 & High \\
\hline 47 & My leader learns the workers how to deal with crises by relying on their knowledge & 4.031 & 0.998 & 18.807 & 0 & 8 & High \\
\hline 48 & My leader make alternative leaders by providing them with mature field experiences & 3.864 & 1.125 & 19.513 & 0 & 15 & High \\
\hline \multirow[t]{2}{*}{49} & My leader has a variety of information on different types of topics & 4.008 & 1.036 & 18.556 & 0 & 11 & High \\
\hline & Avg mean and general SD for experience power & 4.044 & 0.756 & 24.499 & 0 & & High \\
\hline
\end{tabular}

Table 4: Shows the answers of the study sample to the statements related to the experience power in private education in Amman Governorate. 
Citation: Salih AA, Al-Dulaimi MS (2017) Women's Leadership Characteristics and Its Impact in Developing the Psychological Capital: Test of the Moderating Role of Experience Power (Analytical Study from the Perspective of Subordinates in Private Education Schools in Amman). Int J Econ Manag Sci 6: 484. doi: 10.4172/2162-6359.1000484

Governorate. The mathematical averages of the experience power by the women leadership in the private education schools in Amman governorate ranged 3.867-4.199 with a total average of 4.035 on the Likert quintile scale, which indicates the high level of experience by the women leadership in the private education schools in Amman Governorate. The statement "My leader deals with the challenges wisely by consulting her practical experience." Came first while the statement "My leaders make alternative leaders by providing them with mature field experiences" ranked $15^{\text {th }}$ and last.

\section{Test of hypothesis}

First hypothesis H01: The five women's leadership characteristics (empathy, collaboration, patience, intuitiveness and composure) have no impact in developing the psychological capital (self-efficacy, optimism, hope and resiliency) in private schools at a statistical level $(\alpha \leq 0.05)$.

In order to test the first main hypothesis, the multiple variance analysis (MANOVA) was used. After analysis, the results were as in Table 5.

The results of (MANOVA) to verify of the impact of women's leadership characteristics in developing the psychological capital in private schools.

Table 5 clarify the impact of women's leadership characteristics (empathy, collaboration, patience, intuitiveness and composure) in developing the psychological capital (self-efficacy, optimism, hope and resilience) in private schools. The results of the statistical analysis showed that: Empathy variable has significant impact in developing (self-efficacy, optimism and resilience) in private schools, which calculated $\mathrm{F}$ was $(3.241,2.100,2.211)$ respectively at $(\alpha \leq 0.05)$ collaboration variable has impact on both (hope and resilience) in private schools, the calculated $\mathrm{F}$ was (3.004 and 2.435) respectively at ( $\alpha \leq 0.05$ ), patience variable has impact in developing (self-efficacy, hope and resilience) in private schools, the calculated $\mathrm{F}$ was (2.987, $2.211,2.244)$ respectively at $(\alpha \leq 0.05)$, the result of the analysis showed intuitiveness variable has impact in developing (self-efficacy, optimism and hope) in private schools, the calculated $\mathrm{F}$ was $(3.455,2.074,2.598)$ respectively at $(\alpha \leq 0.05)$, finally the results of the analysis showed composure variable impact in developing (self-efficacy, hope and resilience) in private schools, the calculated $\mathrm{F}$ was $(3.349,2.877,3.697)$ respectively at $(\alpha \leq 0.05)$. The summary of the results that we got is every single characteristics of women leadership characteristics has an impact in one variable or more of psychological capital variables, and there's no characteristic impacted in all the psychological capital variables. According to the previous results the first main hypothesis is not accepted, the null hypothesis is rejected and the alternative hypothesis is accepted which is: The five women's leadership characteristics (empathy, collaboration, patience, intuitiveness and composure) have impact in developing the psychological capital (self-efficacy, optimism, hope and resiliency) in private schools at a statistical level $(\alpha \leq 0.05)$.

Second hypothesis H02: There is no change in the impact of women's leadership characteristics (empathy, collaboration, patience, intuitiveness and composure) in developing the psychological capital with the presence of experience power as a moderating role in private schools at $(\alpha \leq 0.05)$.

In order to test the second main hypothesis, the Hierarchical Multiple Regression Analysis was used. After analysis, results were as in Table 6.

\begin{tabular}{|c|c|c|c|c|c|c|}
\hline Source of variance & Dependent variable & Sum of squares & DF & Mean Square & Calculated F & Sig \\
\hline \multirow[t]{4}{*}{ Empathy } & Self-efficacy & 0.448 & 10 & 0.045 & 3.241 & 0.033 \\
\hline & Optimism & 5.576 & 10 & 0.558 & 2.1 & 0.024 \\
\hline & Hope & 2.606 & 10 & 0.261 & 1.147 & 0.327 \\
\hline & Resiliency & 3.672 & 10 & 0.367 & 2.211 & 0.028 \\
\hline \multirow[t]{4}{*}{ Collaboration } & Self-efficacy & 9.643 & 14 & 0.689 & 3.699 & 0.449 \\
\hline & Optimism & 4.267 & 14 & 0.305 & 1.148 & 0.315 \\
\hline & Hope & 7.746 & 14 & 0.553 & 2.435 & 0.003 \\
\hline & Resiliency & 4.264 & 14 & 0.305 & 3.004 & 0 \\
\hline \multirow[t]{4}{*}{ Patience } & Self-efficacy & 6.674 & 12 & 0.556 & 2.987 & 0.001 \\
\hline & Optimism & 2.31 & 12 & 0.193 & 0.725 & 0.727 \\
\hline & Hope & 6.029 & 12 & 0.502 & 2.211 & 0.011 \\
\hline & Resiliency & 4.527 & 12 & 0.377 & 2.244 & 0.025 \\
\hline \multirow[t]{4}{*}{ Intuitiveness } & Self-efficacy & 3.252 & 12 & 0.271 & 3.455 & 0.014 \\
\hline & Optimism & 6.608 & 12 & 0.551 & 2.074 & 0.018 \\
\hline & Hope & 4.358 & 12 & 0.363 & 2.598 & 0.041 \\
\hline & Resiliency & 6.431 & 12 & 0.536 & 1.767 & 0.053 \\
\hline \multirow[t]{4}{*}{ Composure } & Self-efficacy & 8.729 & 14 & 0.623 & 3.349 & 0 \\
\hline & Optimism & 6.099 & 14 & 0.436 & 1.641 & 0.055 \\
\hline & Hope & 12.334 & 14 & 0.881 & 2.877 & 0.006 \\
\hline & Resiliency & 7.205 & 14 & 0.515 & 3.697 & 0 \\
\hline \multirow[t]{4}{*}{ Error } & Self-efficacy & 57.344 & 308 & 0.186 & - & - \\
\hline & Optimism & 81.794 & 308 & 0.266 & - & - \\
\hline & Hope & 69.988 & 308 & 0.227 & - & - \\
\hline & Resiliency & 93.408 & 308 & 0.303 & - & - \\
\hline \multirow[t]{4}{*}{ Total } & Self-efficacy & 5701.188 & 376 & - & - & - \\
\hline & Optimism & 5.691 & 376 & - & - & - \\
\hline & Hope & 5931.188 & 376 & - & - & - \\
\hline & Resiliency & 5973.444 & 376 & - & - & - \\
\hline
\end{tabular}

Table 5: The results of (MANOVA) to verify of the impact of women's leadership characteristics in developing the psychological capital in private schools. 
Citation: Salih AA, Al-Dulaimi MS (2017) Women's Leadership Characteristics and Its Impact in Developing the Psychological Capital: Test of the Moderating Role of Experience Power (Analytical Study from the Perspective of Subordinates in Private Education Schools in Amman). Int J Econ Manag Sci 6: 484. doi: 10.4172/2162-6359.1000484

Page 8 of 10

\begin{tabular}{|c|c|c|c|c|c|c|c|}
\hline \multirow[t]{2}{*}{ Dependent variable } & \multirow[t]{2}{*}{ Independent variable } & \multicolumn{3}{|c|}{ First model } & \multicolumn{3}{|c|}{ Second model } \\
\hline & & Sign & Calculated T & B & Sign & Calculated T & B \\
\hline \multirow[t]{7}{*}{ Psychological capital } & Women's leadership characteristics & 0 & 18.364 & 0.689 & & - & \\
\hline & $\begin{array}{c}\text { Women's leadership characteristics X } \\
\text { experience power }\end{array}$ & \multicolumn{3}{|c|}{-} & 0 & 13.271 & 0.8 \\
\hline & $\mathrm{R}$ & \multicolumn{3}{|c|}{0.689} & \multicolumn{3}{|c|}{0.802} \\
\hline & $\Delta \mathrm{R}^{2}$ & \multicolumn{3}{|c|}{0.474} & \multicolumn{3}{|c|}{0.643} \\
\hline & $\Delta \mathrm{R}^{2}$ & \multicolumn{3}{|c|}{0.474} & \multicolumn{3}{|c|}{0.169} \\
\hline & $\Delta \mathrm{F}$ & \multicolumn{3}{|c|}{337.243} & \multicolumn{3}{|c|}{176.108} \\
\hline & Sig. $\Delta \mathrm{F}$ & \multicolumn{3}{|c|}{0} & \multicolumn{3}{|c|}{0} \\
\hline
\end{tabular}

Table 6: The results of hierarchical multiple regression.

The results of Hierarchical Multiple Regression Analysis to verify the impact of women's leadership characteristics in developing the psychological capital with the presence of experience power as a moderating role in private schools.

Table 6 shows the analysis results of Hierarchical Multiple Regression Analysis that based on two models, the results of the first models showed the value of correlation coefficient $(\mathrm{R}=0.689)$ that proves there's positive correlation between women's leadership characteristics and psychological capital, the results showed there's statistical significance impact of the women's leadership characteristics on the psychological capital, the value of $(\mathrm{F}=337.243)$ With a level of significance $(\mathrm{Sig}=0.000)$ which is less than (0.050). Also the Coefficient of determination value $\left(\mathrm{R}^{2}=474\right)$ which means $(0.474)$ of changes in the psychological capital resulted of the changing of the women's leadership characteristics. The effect degree $\beta$ was (0.689), this means that a one-degree increase in the level of interest in alterations in the women's leadership characteristics leads to (0.689) increase in psychological capital. This indicates that women's leadership characteristics explain $(68.9 \%)$ of the variation in psychological capital.

In the second model, moderating role (experience power) added to Hierarchical Multiple Regression. The value of correlation coefficient increased to $\mathrm{R}=0.802$, also the Coefficient of determination value increased $16.9 \%$, that percentage is statistical function, the change in F value.

$(\Delta \mathrm{F}=176.108)$ with a level of significance (Sig=0.000) which is less than (0.050). Also the effect degree $\beta(0.800)$ for the moderating role (experience power), the value of calculated $\mathrm{T}(\mathrm{t}=13.271)$ with a level of significance $(\operatorname{Sig}=0.000)$, which ensure the moral role for the moderating role (experience power) in improving the impact of women's leadership characteristics on psychological capital. Where the ratio of interpretation of variance in psychological capital has improved by (16.9\%) to increase from (47.4\%) to (64.3). According to that, the null hypothesis is rejected and the alternative hypothesis is accepted which is: there's change in the impact of women's leadership characteristics (empathy, collaboration, patience, intuitiveness and composure) in developing the psychological capital with the presence of experience power as a moderating role in private schools at $(\alpha \leq 0.05)$.

\section{Discussion of Results}

The aim of this study is to describe the women's leadership characteristics and its impact in developing the psychological capital by testing the experience power as a moderating role, and has reached several results, the most important are:

1. The results showed that the level of women leadership characteristics (empathy, collaboration, patience, intuitiveness and composure) in the private education schools in Amman Governorate was high from the perspective of the analysis unit. This indicates the exercise level of women leadership is high in private schools because of the characteristics that the leaders have which enhanced their leadership in effective, successful and influential way on the performance of workers. These characteristics combined in the nature of women led to support her during the positions and enhanced her position in all circumstances that could undermine or weaken the organization and the heads of the Organization. On the other hand, these combined characteristics work on concealing the weaknesses that can emerge in the absence of one; so that they are one integrated unit, one trait supports the other.

2. The results showed that the level of empathy in the private schools in Amman governorate was classified as higher from the viewpoint of the unit of analysis. They have been enhanced through the leader's advice when sought. This is due to the physiological nature of the woman which distinguishes her leadership from males and makes her understand the other. She can evaluate the situation and deal with it wisely and logically, and use a clear and frank way to provide advice. The advice is a result of her constant presence which urges the followers to feel comfortable, safe and confident.

3. The results showed that the level of cooperation in the private schools in Amman governorate was classified as high from the point of view of the analysis unit, but it ranked last in the sequence of characteristics. This indicates that this characteristic needs to be further developed and enhanced by increasing the level of participation and interaction between the leader and workers to increase their level of effectiveness.

4. The results showed that the level of psychological capital (self-efficacy, optimism, hope, and resilience) in the private schools in Amman Governorate was average from the point of view of the analysis unit. This is due to the lack of proper investment in the dimensions of psychological capital and the existence of ineffective practices to invest in, therefore, this result needs to pause and reconsider and find ways and means to increase the effectiveness of investment in it.

5. The results showed that the optimism in the private schools in Amman Governorate, from the point of view of the analysis unit, is the higher dimensions of the psychological capital, so it should be enriched more and focused on the objectives of the organization in terms of employees work and the level of public satisfaction, Which is linked primarily to the quality and strength of employees work.

6. The results showed that resilience in the private schools in Amman Governorate, from the point of view of the unit of analysis is lower than the dimensions of the psychological capital, this is due to the inability to withstand the difficult situations that may result from the inability to return to the normal state of subordinates which in turn leads to the difficulty of dealing with all the behaviors of subordinates 
Citation: Salih AA, Al-Dulaimi MS (2017) Women's Leadership Characteristics and Its Impact in Developing the Psychological Capital: Test of the Moderating Role of Experience Power (Analytical Study from the Perspective of Subordinates in Private Education Schools in Amman). Int J Econ Manag Sci 6: 484. doi: 10.4172/2162-6359.1000484

with some of them or subordinates and leaders, and hence the subordinate feels that hard work and perseverance reduce the negative emotions that affect, but the fact that the quality of work performance is not the required level.

7. The results showed that the experience power in the private schools in Amman Governorate from the point of view of the analysis unit was high. This is an affirmation of the fact that the experience power is in the hands of the principals along with the official power, and thus the power of expertise will enable the leaders to deal with all forms and conditions of work in a practical and rapid manner away from trial and error.

8. The results of the statistical analysis showed a statistically significant impact of the women's leadership characteristics in developing the psychological capital in private schools. This means that the increase in the level of attention to the women's leadership characteristics lead to the development of psychological capital in private schools.

9. The results of the statistical analysis confirm that the impact of women leadership characteristics in developing the psychological capital in private schools increases with the presence of experience power as a moderating role. This increase is positive, which means that the level of performance will increase significantly by the experience power on the relationship between characteristics and psychological capital.

\section{Recommendations and Proposals} following:

Based on the findings of the study, the researcher recommends the

1. To increase and enhance the practice of women's leadership characteristics that has a positive impact on employees. Through increased support of senior management, documentation of successful experiences, and capacity development through specialized training and development programs.

2. The need to pay more attention to psychological capital due to its importance and its impact on the psychology and work of the individuals in the organization and the benefits and competitive advantage of the organization.

3. Allow women in the fields of recruitment and engage them more in the work to enrich their experience power.

4. The necessity of not limiting women to being a woman only and to depart this negative culture because a woman, as the current study has reached has high leadership skills that have enabled her to excel in her work.

5. Help the women to break the glass ceiling that she faces it in the organizations.

6. The researcher recommends continuing the research in the topic of women's leadership characteristics because of their availability, yet not much writing has been conducted, and the urge to invest in the psychological capital, through further studies where there is a clear lack of these studies on the one hand and the urgent need on the other hand.

7. The researcher recommends the examination of the women leadership characteristics and the experience power with the introduction of the desire in learning as a moderator variable.
8. Conducting a study of the impact of women leadership characteristics in the development of work with the presence of psychological capital as a Variable moderator and the experience power as a moderating role.

\section{References}

1. Avey J, Luthans F, Smith R, Palmer N (2010) Impact of positive psychological capital on employee well-being over time. Journal of Occupational Health Psychology 15: 17-28.

2. Murray CD (2014) A qualitative study on minority men and women's perceived barriers to senior executive service advancement. Available from ProQuest Dissertations \& Theses Global: Business.

3. Weidenfeller NK (2012) Breaking through the glass wall: the experience of being a woman enterprise leader. Human Resource Development International 15: $365-374$

4. Cook A, Glass C (2014) Women and Top Leadership Positions: Towards an Institutional Analysis. Gender, Work \& Organization 21: 91-103.

5. Heckman M (2014) Where the women are: Measuring female leadership in the new journalism ecology. Available from ProQuest Dissertations \& Theses Global.

6. Petru A (2015) Women's leadership mean in 2015? A 3p Series in Partnership with MGM Resorts Foundation. Triple Pundit.

7. Rouleau-Carroll L (2014) Attributes and characteristics that contribute to successful female leadership in secondary education. Available from ProQuest Dissertations \& Theses Global.

8. Javidan M, Walker JL (2013) Developing Your Global Mind set the Handbook for Successful Global Leaders. Beaver's Pond Press.

9. Lumby J, Azaola MC (2014) Women principals in South Africa: gender mothering and leadership. British Educational Research Journal 40: 30-44

10. Drasin J (2014) Employee trust in leadership as a moderator for stress brough on by organizational change Available from ProQuest Dissertations \& Theses Global: Business.

11. Galuppo L, Gorli M, Ripamonti S (2011) Playing Dissymmetry in Action Research: The Role of Power and Differences in Promoting Participative Knowledge and Change. Systemic Practice \& Action Research 24: 147-164.

12. Desvaux G, Devillard-Hoellinger S, Baumgarten P (2007) Women matter: Gender diversity, a corporate performance driver. McKinsey.

13. Luthans F, Avolio BJ, James B, Norman SM (2007) Positive Psychological Capital: Measurement and Relationship with Performance and Satisfaction.

14. Corner KJ (2015) Exploring the reliability and validity of research instruments to examine secondary school principals' authentic leadership behavior and psychological capital. Available from ProQuest Dissertations \& Theses Global: Business.

15. Bockorny KM (2015) Psychological capital, courage, and entrepreneurial success. Available from ProQuest Dissertations \& Theses Global: Business.

16. Toogood KJ (2012) Living the complexity of female leadership: Beyond the binder, back to our hearts. Available from ProQuest Dissertations \& Theses Global.

17. Political Development Forum (2009) promoting women leadership in parties, consultation.

18. Pelkey-Landes F (2002) Exploring and advancing female leadership in nonprofit organizations and private corporations. Available from ProQuest Dissertations \& Theses Global.

19. Shermerhorn J (2005) Management (8thedn), Willey \& Sons, New York, USA.

20. Vasavada $T$ (2012) A cultural feminist perspective on leadership in nonprofit organizations: a case of women leaders in India. Public Administration Quarterly 36: 462-503.

21. McCullough TA (2012) A phenomenological study about female politica leaders. Available from ProQuest Dissertations \& Theses Global: Business.

22. Fahmy M (2013) Female leadership in Islamic schools in the United States of America: Prevalence, obstacles, and challenges. Available from ProQuest Dissertations \& Theses Global. 
Citation: Salih AA, Al-Dulaimi MS (2017) Women's Leadership Characteristics and Its Impact in Developing the Psychological Capital: Test of the Moderating Role of Experience Power (Analytical Study from the Perspective of Subordinates in Private Education Schools in Amman). Int J Econ Manag Sci 6: 484. doi: 10.4172/2162-6359.1000484

Page 10 of 10

23. Grant J (1988) Women Manager: What they can offer to organizations. Organizational Dynamics 15: 56-63

24. Poon $R$ (2013) The impact of securely attached and integrated leadership on follower mental health and psychological capital. Available from ProQuest Dissertations \& Theses Global: Business.

25. Peterson SJ, Byron K (2008) Exploring the role of hope in job performance: Results from four studies. Journal of Organizational Behavior 29: 785-803.

26. Quisenberry DM (2015) Testing the internal validity of psychological capital: A laboratory experiment utilizing neurophysical and psychological measures. Available from ProQuest Dissertations \& Theses Global: Business.

27. Chen DJ, Lim VK (2012) Strength in adversity: The influence of psychological capital on job search. Journal of Organizational Behavior 33: 811-839.

28. Lima JL (2015) Power, trust, police unions, and police managers: A quantitative research study. Available from ProQuest Dissertations \& Theses Global: Business.

29. Lentz KM (2013) Empowerment and human agency: The role of power transfer control, and intentional actions by leaders on behalf of an organization. Available from ProQuest Dissertations \& Theses Global.

30. Masten A (2001) Ordinary magic: Resilience Processes in Development. American Psychological Association.

31. Cole K (2007) Good for the soul: The relationship between work, wellbeing and psychological capital. The Journal of Socio-Economics 38: 464-474.

32. Seligman ME (2011) Learned optimism: How to change your mind and your life. Vintage.

33. Al-salem M (2009) Organizational strength. Amman: Ithra'a for publication and distribution.

34. Al-Karyoti M (2006) Organization theory and organize. Amman: Wael for publication.

35. Greenberg J, Baron R (2004) Behavior in Organization. A Pearson Education Company.

36. Sutherland I, Gosling JR, Jelinek J (2015) Aesthetics of Power: Why Teaching about power is easier than learning for power, and what business schools could do about it. Academy of management learning \& education 14: 607-624.

37. Brescoll VL (2011) Who Takes the Floor and Why: Gender, Power, and Volubility in Organizations. Administrative Science Quarterly 56: 622-641.

38. Ashforth BE, Schinoff BS, Rogers KM (2016) "I identify with her," "I identify with him": Unpacking the dynamics of personal identification in organizations. Academy of Management Review 41: 28-60.

39. Jones G (2013) Organizational Theory, Design, and Change (7thedn), Pearson Higher Education USA.

40. Bal V, Campbell M, Steed J, Meddings K (2008) The Role of Power in Effective Leadership. Center Enter For Creative Leadership.

41. Robbins S, Judge T (2015) Organizational behavior (16thedn), Pearson Education, United States.

42. Schuh S, Hernandez BA, Van Q, Hossiep N, Frieg R, et al. (2014) Gender Differences in Leadership Role Occupancy: The Mediating Role of Power Motivation. Journal of Business Ethics 120: 363-379.

43. Sanders S, Wisse BM, Van Yperen NW (2015) Holding Others in Contempt: the Moderating Role of Power in the Relationship Between Leaders' Contempt and their Behavior Vis-à-vis Employees.Business Ethics Quarterly 25: 213-241.

44. Scovetta V (2013) The impact of leadership social power on knowledge management success. Available from ProQuest Dissertations \& Theses Global: Business.

45. Avey JB, Luthans F, Jensen SM (2009) Psychological capital: A positive resource for combating employee stress and turnover. Human resource management 48: 677-693.

46. Chan AYL (2010) Reflecting on experience for leadership development (Order No. 3398298). Available from ProQuest Dissertations \& Theses Global: Business.

47. Hashemite Kingdom of Jordan, Ministry of Education, Law of Education No. 3 of 1994; Article 2 of the Regulations for the Establishment and Licensing of Private and Foreign Educational Institutions No. 130 of 2015. 